\title{
A Four Coordinated Iron(II)-Digermyl Complex as an Effective Precursor for the Catalytic Dehydrogenation of Ammonia Borane
}

\author{
Yoshinao Kobayashi ${ }^{1}$ and Yusuke Sunada ${ }^{1,2, * \mathbb{D}}$ \\ 1 Department of Applied Chemistry, School of Engineering, The University of Tokyo, \\ 4-6-1 Komaba Meguro-ku, Tokyo 153-8580, Japan; yk504@iis.u-tokyo.ac.jp \\ 2 Institute of Industrial Science, The University of Tokyo, 4-6-1 Komaba Meguro-ku, Tokyo 153-8580, Japan \\ * Correspondence: sunada@iis.u-tokyo.ac.jp; Tel.: +81-3-5452-6361
}

Received: 11 December 2019; Accepted: 24 December 2019; Published: 25 December 2019

\begin{abstract}
A coordinatively unsaturated iron(II)-digermyl complex, Fe[Ge( $\left.\left(\mathrm{SiMe}_{3}\right)_{3}\right]_{2}(\mathrm{THF})_{2}$ (1), was synthesized in one step by the reaction of $\mathrm{FeBr}_{2}$ with 2 equiv of $\mathrm{KGe}\left(\mathrm{SiMe}_{3}\right)_{3}$. Complex $\mathbf{1}$ shows catalytic activity comparable to that of its silicon analogue in reduction reactions. In addition, 1 acts as an effective precursor for the catalytic dehydrogenation of ammonia borane. Catalytically active species can also be generated in situ by simple mixing of the easy-to-handle precursors $\mathrm{FeBr}_{2}$, $\mathrm{Ge}\left(\mathrm{SiMe}_{3}\right)_{4}, \mathrm{KO}^{\mathrm{t}} \mathrm{Bu}$, and phenanthroline.
\end{abstract}

Keywords: iron catalyst; organogermyl ligand; reduction; dehydrogenation

\section{Introduction}

Group 14 ligands stabilize coordinatively unsaturated transition-metal centers due to their strong $\sigma$-donating properties and high trans-influence [1-5]. Among these, organosilyl ligands especially are widely used as supporting ligands. The creation of coordinatively unsaturated complexes is one of the most straightforward ways to develop efficient catalyst systems, especially in the field of base-metal catalysis [6-11], as base-metal compounds are usually obtained as coordinatively saturated species that exhibit low reactivity. The introduction of organosilyl ligands thus represents a potentially effective strategy to develop base-metal catalysts. We have recently reported that the four-coordinated iron(II)-disilyl complex $\mathrm{Fe}\left[\mathrm{Si}\left(\mathrm{SiMe}_{3}\right)_{3}\right]_{2}(\mathrm{THF})_{2}(2)$ exhibits a coordinatively unsaturated character and can thus act as an effective catalyst for reduction reactions [12]. Notably, 2 can be synthesized easily via the reaction of a commercially available iron salt with silyl anions.

Recently, the use of heavier-group-14 elements other than silicon has also been identified as a potentially effective strategy to develop highly active catalysts. For instance, Iwasawa and Takaya have examined the catalytic activity of Pd complexes that bear PSiP or PGeP pincer-type ligands in the hydrocarboxylation of allenes, and found that the latter exhibit superior catalytic performance relative to the former [13-15]. However, examples of iron complexes that contain heavier-group-14 ligands, such as organogermyl ligands, remain scarce due to a lack of synthetic methods [16-20]. Most iron-organogermyl complexes have been obtained from the reactions of an iron precursor with organogermanes that bear Ge-H moieties; however, coordinatively saturated species are often formed via this route. Based on the synthetic route to Complex 2, we hypothesized that a structurally similar coordinatively unsaturated iron(II)-digermyl complex could be accessed easily by using organogermyl anions instead of organosilyl anions. Herein, we report the corresponding synthesis of the germanium analogue of $\mathbf{2}$ and describe the catalytic performance of the resulting complex. Iron-digermyl Complex $\mathbf{1}$ was found to act as a good catalyst precursor for reduction reactions and the dehydrogenation of ammonia borane $\left(\mathrm{NH}_{3} \cdot \mathrm{BH}_{3}\right)$. 


\section{Results and Discussion}

\subsection{Synthesis of Iron-Digermyl Complex $\mathbf{1}$}

Based on a slight modification of the method reported by Marschner et al. [21], the potassium salt of the tris(trimethylsilyl)germyl anion, $\mathrm{KGe}\left(\mathrm{SiMe}_{3}\right)_{3}$, was easily generated by treating $\mathrm{Ge}\left(\mathrm{SiMe}_{3}\right)_{4}$ with 1.05 equiv of $\mathrm{KO}^{\mathrm{t}} \mathrm{Bu}$ in THF. A THF solution of $\mathrm{KGe}\left(\mathrm{SiMe}_{3}\right)_{3}$ was then treated for $1 \mathrm{~h}$ with 0.5 equiv of iron(II) bromide at room temperature to furnish iron(II) digermyl complex $\mathrm{Fe}\left[\mathrm{Ge}\left(\mathrm{SiMe}_{3}\right)_{3}\right]_{2}(\mathrm{THF})_{2}$ (1) in $74 \%$ yield as red-purple crystals (Scheme 1 ).

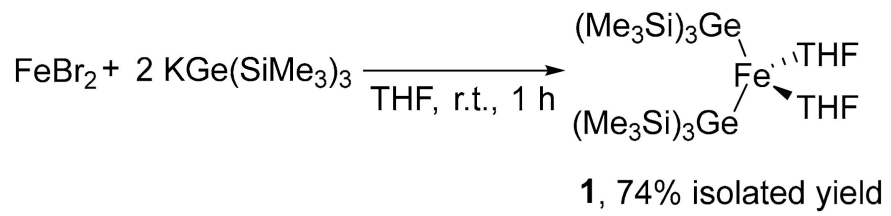

Scheme 1. Synthesis of Iron-Digermyl Complex 1.

Similar to its silicon analogue 2, 1 quickly decomposes upon exposure to air or moisture. The molecular structure of $\mathbf{1}$ was determined by single-crystal X-ray diffraction analysis, and an ORTEP drawing of the molecular structure of $\mathbf{1}$ is depicted in Figure 1. Complex $\mathbf{1}$ adopts a distorted tetrahedral coordination geometry around its iron center, presumably due to the steric repulsion between the two $\mathrm{Ge}\left(\mathrm{SiMe}_{3}\right)_{3}$ ligands. The $\mathrm{Ge}-\mathrm{Fe}-\mathrm{Ge}$ angle of $\mathbf{1}\left(134.77(4)^{\circ}\right)$ is comparable to the analogous $\mathrm{Si}-\mathrm{Fe}-\mathrm{Si}$ angle in the silicon analogue $2\left(135.23(3)^{\circ}\right)$. The Fe-Ge bond is slightly elongated (2.5589(8) $\AA$ ) compared to those of previously reported iron-organogermyl complexes [17-19,22-26].

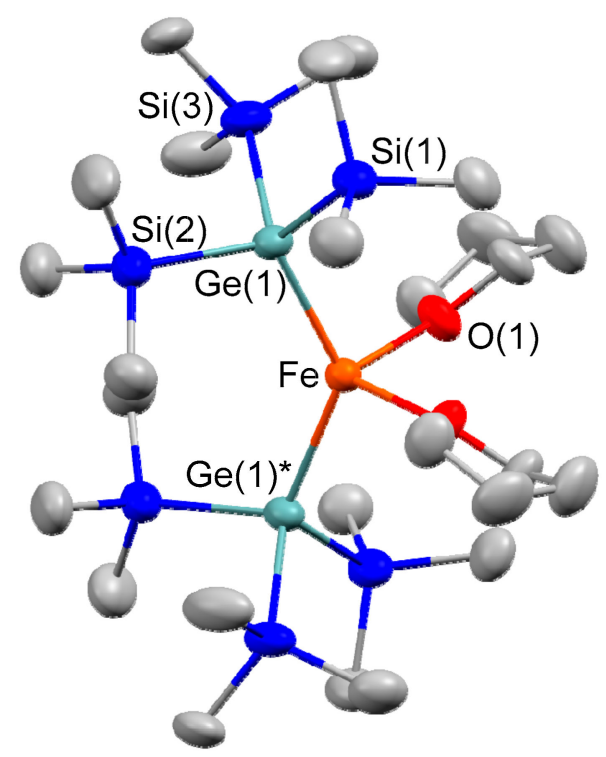

Figure 1. Molecular structure of $\mathbf{1}$ with $50 \%$ probability ellipsoids. All hydrogen atoms were omitted for clarity.

In the ${ }^{1} \mathrm{H}$ NMR spectrum of $\mathbf{1}$, a broad singlet assignable to the $\mathrm{SiMe}_{3}$ group appeared at $8.67 \mathrm{ppm}$, and two broad signals corresponding to two molecules of THF coordinated to the iron center were observed at 24.02 and 29.42 ppm, respectively. These spectral features indicate that $\mathbf{1}$ is paramagnetic; the magnetic moment of $\mathbf{1}$ estimated using the Evans method [27-29] is consistent with a high-spin $S=$ 2 ground state $\left(\mu_{\text {eff }}=4.85\right)$. Despite its high sensitivity toward air and moisture, the elemental analysis of $\mathbf{1}$ was satisfactory. 


\subsection{Catalytic Performance of $\mathbf{1}$ toward Reduction Reactions}

In our previous paper, 2 was found to exhibit good catalytic performance in reduction reactions, namely, the hydrosilylation of ketones and the reductive silylation of dinitrogen. A key aspect of these catalytic reactions is the fact that the organosilyl ligands promote the creation of a reaction site on the iron center owing to their high $\sigma$-electron donating ability and their strong trans-influence. In other words, coordinatively unsaturated catalytically active species are effectively generated in situ via the dissociation of THF. As $\mathbf{2}$ is a structural analogue of $\mathbf{1}$, we tested the catalytic performance of $\mathbf{1}$ in the two reduction reactions mentioned above.

Initially, we examined the 1-catalyzed hydrosilylation of ketones with $\mathrm{Ph}_{2} \mathrm{SiH}_{2}$. 4-Acetylbiphenyl and 4-phenyl-2-butanone were selected as representative aromatic and aliphatic ketones (Scheme 2). The hydrosilylation of 4-acetylbiphenyl with $\mathrm{Ph}_{2} \mathrm{SiH}_{2}$ in the presence of $0.1 \mathrm{~mol} \%$ of $\mathbf{1}$ in dioxane at room temperature proceeded smoothly to afford the corresponding silyl-ether in quantitative yield within $4 \mathrm{~h}$. Similarly, complete conversion of cyclohexanone was confirmed within $4 \mathrm{~h}$ when the reaction was conducted using $\mathrm{Ph}_{2} \mathrm{SiH}_{2}$ and $0.1 \mathrm{~mol} \%$ of 1 at room temperature. It should be noted here that the catalysis mediated by the silicon analogue 2 was carried out under the reaction conditions shown in Scheme 2, indicating that the catalytic activity of $\mathbf{1}$ toward the hydrosilylation of ketones is comparable to that of 2 .

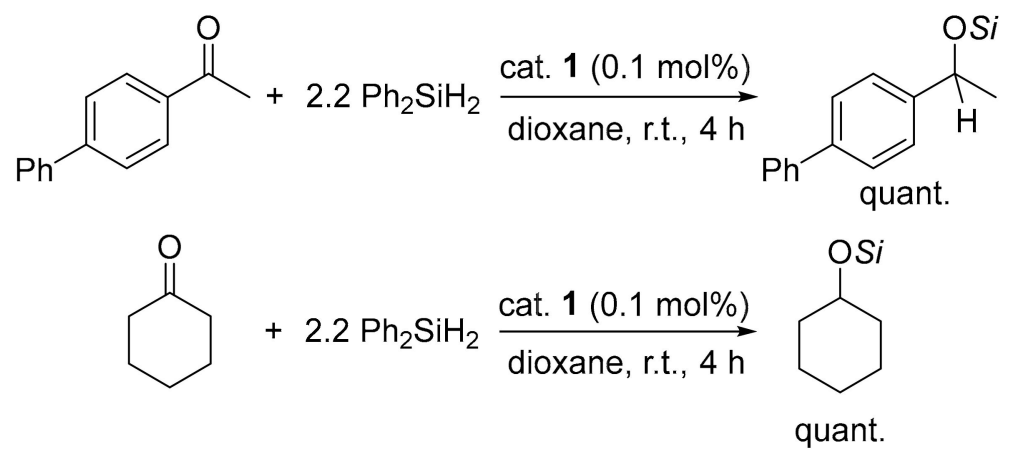

Scheme 2. Catalytic hydrosilylation of ketones catalyzed by 1 .

Next, we examined the reductive silylation of dinitrogen catalyzed by 1 . The reductive silylation of atmospheric dinitrogen was achieved using an excess of $\mathrm{SiMe}_{3} \mathrm{Cl}$ and $\mathrm{KC}_{8}$ at room temperature in the presence of $0.2 \mathrm{~mol} \%$ of $\mathbf{1}$. During this reaction, the formation of 11.4 equiv of $\mathrm{N}\left(\mathrm{SiMe}_{3}\right)_{3}$ per $\mathrm{Fe}$ atom was observed in THF, concomitant with the generation of byproducts including $\mathrm{Me}_{3} \mathrm{Si}_{-} \mathrm{SiMe}_{3}$ and mono- and bis-silylated ring-opened THF, i.e., $\mathrm{Me}_{3} \mathrm{SiO}\left(\mathrm{CH}_{2}\right)_{3} \mathrm{CH}_{2} \mathrm{R}\left(\mathrm{R}=\mathrm{H}\right.$ or $\left.\mathrm{SiMe}_{3}\right)$. However, the TON of the reaction catalyzed by 2 reached 22.9; thus, the catalytic performance of 1 seems to have decreased slightly due to the replacement of silicon by germanium as the coordinating atom.

\subsection{Catalytic Dehydrogenation of Ammonia Borane Catalysed by $\mathbf{1}$}

These results indicate that catalytic performance of $\mathbf{1}$ in reduction reactions is decent. In addition to these reduction reactions, we found that $\mathbf{1}$ also promotes a catalytic oxidation reaction, i.e., the dehydrogenation of $\mathrm{NH}_{3} \cdot \mathrm{BH}_{3}$, when the appropriate reagents are used. $\mathrm{NH}_{3} \cdot \mathrm{BH}_{3}$ has been identified as an appropriate solid hydrogen-storage material due to its high hydrogen content, and accordingly, the catalytic production of hydrogen via the dehydrogenation of $\mathrm{NH}_{3} \cdot \mathrm{BH}_{3}$ has attracted great attention. Recently, numerous transition-metal-mediated reactions have been developed based on the design and synthesis of appropriate catalysts [30-32]. Among these, iron-based catalysts represent some of the most promising candidates for the development of practical systems owing to their low cost, earth-abundance, and low toxicity [33-42]. Thus, great efforts have been devoted to developing iron-mediated reactions for the dehydrogenation of ammonia borane derivatives. For instance, Baker reported that the iron catalyst (dcpe) $\mathrm{Fe}\left(\mathrm{N}(\mathrm{Ph}) \mathrm{CH}_{2} \mathrm{CH}_{2}(\mathrm{Ph}) \mathrm{N}\right)$ [dcpe = 1,2-bis(dicyclohexylphosphino)ethane], which contains 
a chelating diamide ligand, exhibits high catalytic performance and could complete the reaction within 15 min even at room temperature [33]. Several examples of iron catalysts that contain pincer-type ligands have also been reported to show good catalytic performance for this reaction [43]. For instance, the iron catalyst (PNP) Fe(H)(CO) $\left[\mathrm{PNP}=\mathrm{N}\left(\mathrm{CH}_{2} \mathrm{CH}_{2} \mathrm{P}^{\mathrm{i}} \mathrm{Pr}\right)_{2}\right]$, which contains a PNP pincer ligand, was reported by Schneider et al. and shows exceptionally high catalytic activity at room temperature [34]. Complete consumption of $\mathrm{NH}_{3} \cdot \mathrm{BH}_{3}$ was confirmed at catalyst loadings as low as $0.5 \mathrm{~mol} \%$. A theoretical study revealed that the cooperative function between the iron center and the nitrogen atom of the PNP ligand plays a crucial role in the activation of $\mathrm{NH}_{3} \cdot \mathrm{BH}_{3}$ in this catalytic reaction. Despite the large number of iron-catalyzed dehydrogenation reactions that have been developed, almost all require the synthesis of iron catalysts that bear bespoke and often difficult-to-synthesize auxiliary ligands or that are difficult to isolate due to their sensitivity toward air and/or moisture. An exceptional example was introduced by Manners and co-workers, who reported that the commercially available dinuclear iron catalyst $\left[\mathrm{CpFe}(\mathrm{CO})_{2}\right]_{2}\left(\mathrm{Cp}=\eta^{5}-\mathrm{C}_{5} \mathrm{H}_{5}{ }^{-}\right)$can effectively catalyze the dehydrogenation of $\mathrm{Me}_{2} \mathrm{NH} \cdot \mathrm{BH}_{3}$ under irradiation from a medium-pressure mercury lamp $[35,36]$. The $\left[\mathrm{CpFe}(\mathrm{CO})_{2}\right]_{2}$-catalyzed dehydrogenation of $\mathrm{NH}_{3} \cdot \mathrm{BH}_{3}$ under irradiation from an LED lamp was achieved by Waterman et al. [37]. However, in these catalytic reactions, continuous irradiation is required.

We discovered that $\mathrm{NH}_{3} \cdot \mathrm{BH}_{3}$ underwent dehydrogenation at $55{ }^{\circ} \mathrm{C}$ in the presence of a catalytic amount of $\mathbf{1}$ and the appropriate auxiliary ligand and additive. Initially, we treated $\mathrm{NH}_{3} \cdot \mathrm{BH}_{3}$ in THF $(0.1 \mathrm{M})$ at $55{ }^{\circ} \mathrm{C}$ with $5 \mathrm{~mol} \%$ of $\mathbf{1}$ in the presence of ${ }^{\mathrm{t}} \mathrm{BuOH}(5 \mathrm{~mol} \%)$ and a series of auxiliary ligands. As shown in Table 1, phenanthroline, bathophenanthroline, a diimine, an $\mathrm{N}$-heterocyclic carbene (NHC), $N, N, N^{\prime}, N^{\prime}$-tetramethylethylenediamine (TMEDA), and pyridine were examined. We found that the addition of phenanthroline resulted in the highest conversion of $\mathrm{NH}_{3} \cdot \mathrm{BH}_{3}$ (Entry 2), while the more electron-withdrawing ligand bathophenanthroline was less effective. The reaction also proceeded with lower conversion in the presence of the $\pi$-accepting diimine ligand. In contrast, the combination of 1 and the $\sigma$-donating nitrogen-based ligands TMEDA and pyridine resulted in negligible catalytic activity (Entries 8 and 9), while the addition of the $\mathrm{NHC}^{i} \operatorname{Pr}_{2} \mathrm{IM}^{\mathrm{Me}}$ furnished the dehydrogenated product in $32 \%$ (Entry 7). The reaction did not occur in the absence of an additional auxiliary ligand (Entry 1). The optimal ratio of $1{ }^{\mathrm{t}} \mathrm{BuOH}$ was found to be $1: 1$, and the conversion of $\mathrm{NH}_{3} \cdot \mathrm{BH}_{3}$ decreased when the amount of ${ }^{\mathrm{t}} \mathrm{BuOH}$ was increased $\left(1:^{\mathrm{t}} \mathrm{BuOH}=1: 2\right.$; Entry 3$)$. The conversion increased slightly when the reaction time was extended to $72 \mathrm{~h}$ (Entry 4 ). ${ }^{11} \mathrm{~B}\left\{{ }^{1} \mathrm{H}\right\}$ and ${ }^{11} \mathrm{~B}$ NMR spectroscopic measurements revealed that $\mathrm{NH}_{3} \cdot \mathrm{BH}_{3}$ was converted into 3, 4 and 5 in a ca. 3:5:8 molar ratio in each case [44]. 
Table 1. Dehydrogenation of ammonia borane catalyzed by combination of $\mathbf{1},{ }^{\mathrm{t}} \mathrm{BuOH}$, and ligands ${ }^{\mathrm{a}}$.

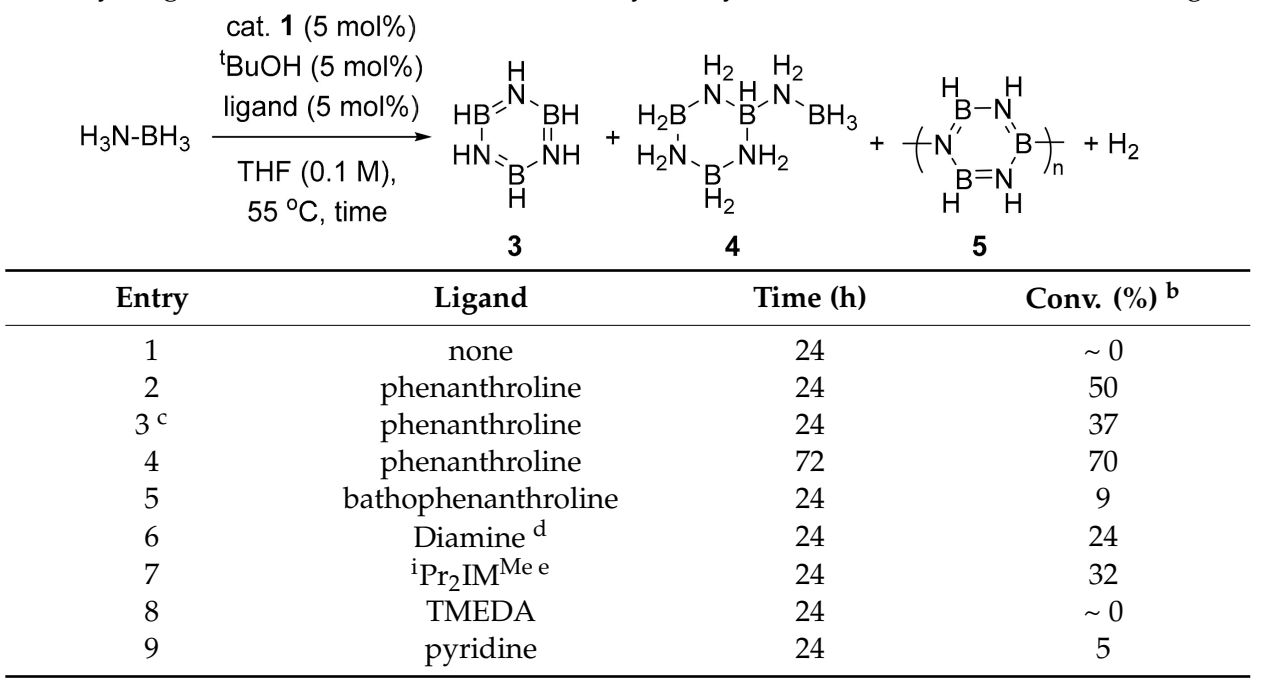

\footnotetext{
a All reactions were carried out with ammonia borane $(0.5 \mathrm{mmol})$, catalytic amount of $\mathbf{1}(5 \mathrm{~mol} \%),{ }^{\mathrm{t}} \mathrm{BuOH}(5 \mathrm{~mol} \%)$, and ligand $(5 \mathrm{~mol} \%)$ at $55^{\circ} \mathrm{C}$ in THF $(5 \mathrm{~mL})$. ${ }^{\mathrm{b}}$ Conversion of ammonia borane was determined by ${ }^{11} \mathrm{~B}$ NMR. ${ }^{\mathrm{c}}$ reaction was performed with $10 \mathrm{~mol} \%$ of ${ }^{\mathrm{t}} \mathrm{BuOH} .{ }^{\mathrm{d}}$ diimine $=2,3$-bis(2,4,6-trimethylphenylimino)butane. ${ }^{\mathrm{e}} \mathrm{Pr}_{2} \mathrm{IM}^{\mathrm{Me}}$ =1,3-diisopropyl-4,5-dimethyl-imidazol-2-ylidene.
}

After optimization of the auxiliary ligand, further screening of the other additives, except for ${ }^{t} \mathrm{BuOH}$, was performed. As noted above, $\mathrm{NH}_{3} \cdot \mathrm{BH}_{3}$ has been reported to be effectively activated in a cooperative fashion over the Fe- $\mathrm{N}$ bond in several iron catalysts. We therefore examined the potential generation of catalytically active species with Fe-N bonds by using amine additives (Table 2; Entries 4-8). As expected, the yield of the dehydrogenated product increased in the reactions shown in Entries 4-7. Among these, ${ }^{\mathrm{t}} \mathrm{BuNH}_{2}$ was identified as the most effective additive, which furnished $76 \%$ conversion of $\mathrm{NH}_{3} \cdot \mathrm{BH}_{3}$ into 3, 4, and 5. In contrast, the addition of 2,6-diisopropylaniline decreased the conversion, presumably due to the increased steric hinderance around the Fe- $\mathrm{N}$ bond (Entry 8). The dehydrogenation of $\mathrm{NH}_{3} \cdot \mathrm{BH}_{3}$ also occurred in the presence of an aliphatic carboxylic acid, though the products were obtained in lower yield. It should be noted that the use of the iron complex 2 instead of 1 resulted in a slight increase in the conversion under the same reaction conditions (Entry 3). 
Table 2. Dehydrogenation of ammonia borane catalyzed by combination of $\mathbf{1}$, phenanthroline, and additives ${ }^{\mathrm{a}}$.

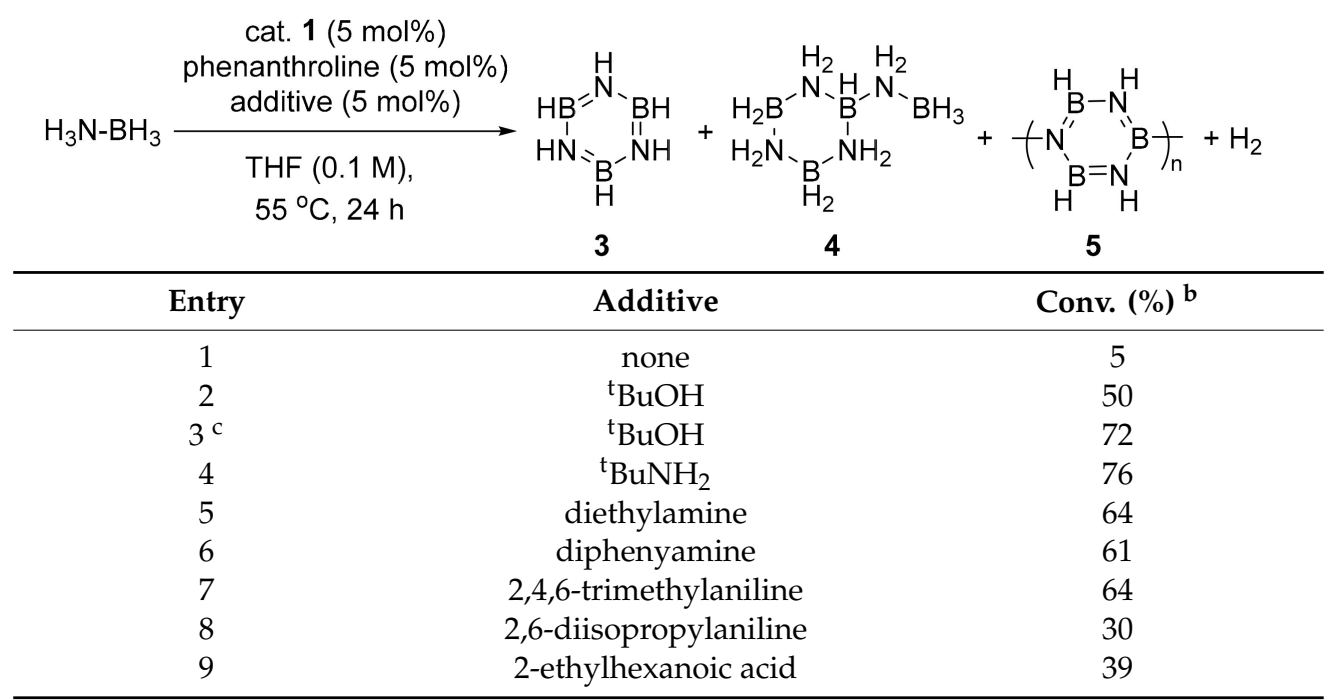

\footnotetext{
a All reactions were carried out with ammonia borane $(0.5 \mathrm{mmol})$, a catalytic amount of 1 ( $5 \mathrm{~mol} \%)$, phenanthrolne ( $5 \mathrm{~mol} \%$ ), and additives $(5 \mathrm{~mol} \%)$ at $55^{\circ} \mathrm{C}$ in THF $(5 \mathrm{~mL})$ for $24 \mathrm{~h} .{ }^{\mathrm{b}}$ Conversion of ammonia borane was determined by ${ }^{11} \mathrm{~B}$ NMR. ${ }^{\mathrm{c}}$ Complex 2 was used instead of $\mathbf{1}$.
}

The organogermyl anion $\mathrm{KGe}\left(\mathrm{SiMe}_{3}\right)_{3}$ can be quantitatively generated in situ by the reaction of $\mathrm{Ge}\left(\mathrm{SiMe}_{3}\right)_{4}$ and $\mathrm{KO}^{\mathrm{t}} \mathrm{Bu}$ in THF. Thus, we hypothesized that the catalytically active species for the dehydrogenation of $\mathrm{NH}_{3} \cdot \mathrm{BH}_{3}$ could be easily generated in situ by simply mixing $\mathrm{FeBr}_{2}, \mathrm{Ge}\left(\mathrm{SiMe}_{3}\right)_{4}$, $\mathrm{KO}^{\mathrm{t}} \mathrm{Bu}$, and phenanthroline. In fact, $\mathrm{NH}_{3} \cdot \mathrm{BH}_{3}$ could be dehydrogenated using this catalyst system, and the conversion reached 26\% (Scheme 3). Although the conversion was lower than that obtained by the reaction catalyzed by isolated $\mathbf{1}$, it should be noted that all the reagents used in the present catalysis are easily available and easy to handle. Thus, the catalysis shown in Scheme 3 should allow for a practical and convenient catalytic dehydrogenation of $\mathrm{NH}_{3} \cdot \mathrm{BH}_{3}$ via a base-metal catalyst.

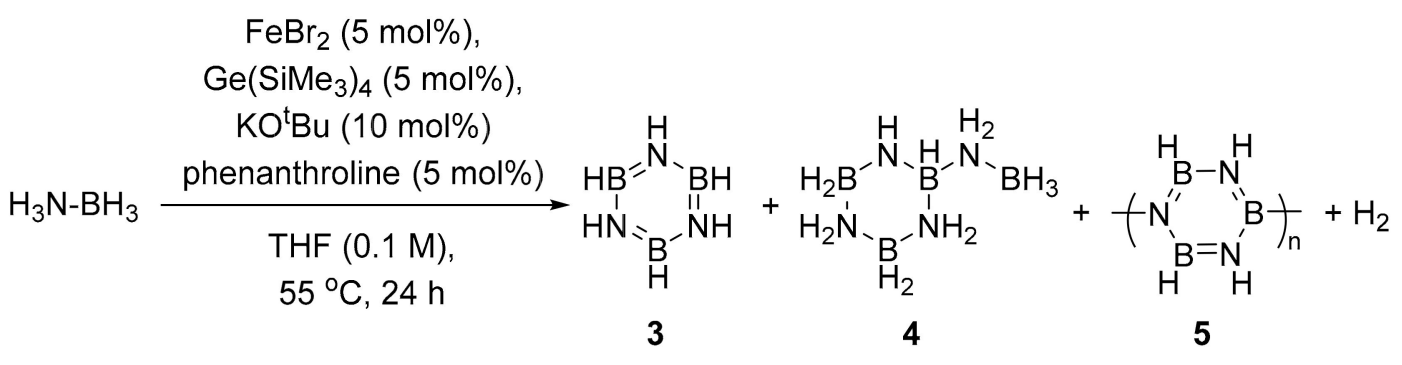

$26 \%$ converstion

Scheme 3. In situ generation of catalytically active species.

To gain some insight into the reaction mechanism of the dehydrogenation of ammonia borane, a stoichiometric reaction between 1 and ${ }^{\mathrm{t}} \mathrm{BuOH}$ was performed in THF at room temperature. Although the isolated yield was relatively low $(\sim 5 \%)$, the dinuclear iron complex 6 , which contains a bridging $\mathrm{O}^{t} \mathrm{Bu}$ group, was formed in this reaction (Scheme 4). Complex 6 was also obtained from the reaction of $\mathrm{FeBr}_{2}, \mathrm{KGe}\left(\mathrm{SiMe}_{3}\right)_{3}$, and $\mathrm{KO}^{\mathrm{t}} \mathrm{Bu}$ in a 1:1:1 ratio in THF (details are shown in the supporting information). The molecular structure was determined via single-crystal X-ray diffraction analysis, and the structural parameters are summarized in the supporting information. It is interesting to note that one of the two iron centers adopts three-coordinated trigonal planar geometry. These results suggests that the catalytically active species may be the mononuclear iron species "(phenanthroline) $\left[\mathrm{Ge}\left(\mathrm{SiMe}_{3}\right)_{3}\right] \mathrm{Fe}\left(\mathrm{O}^{\mathrm{t}} \mathrm{Bu}\right)$," which was generated in situ via the cleavage of the $\mathrm{Fe}-\mathrm{O}$ bond of 6 , and the coordination of phenanthroline. The higher $\sigma$-electron-donating properties 
and the stronger trans-influence of the organosilyl ligand compared to the organogermyl ligand may allow for a more effective cleavage of the bridging $\mathrm{Fe}-\mathrm{O}$ bond, leading to the somewhat superior catalytic activity of $\mathbf{2}$ compared to $\mathbf{1}$. However, it should be emphasized here that the structurally similar silyl analogue of $\mathbf{6}$ could not be accessed via a reaction analogous to that shown in Scheme 4 starting from 2 . The decomposition of the product might be ascribed to the high oxo-affinity of silicon. Thus, the use of the organogermyl ligand contributed to the elucidation of the reaction mechanism by stabilizing the intermediary species.

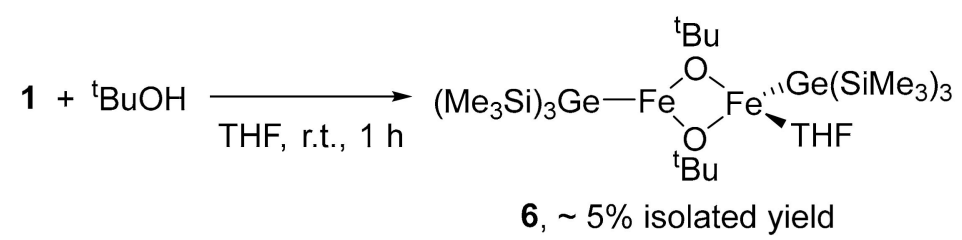

Scheme 4. Reaction of $\mathbf{1}$ and 1 equiv of ${ }^{\mathrm{t}} \mathrm{BuOH}$ to afford the dinuclear complex 3.

\section{Materials and Methods}

Manipulation of air and moisture sensitive compounds was carried out under a dry nitrogen atmosphere using Schlenk tube techniques associated with a high-vacuum line or in the glove box which was filled with dry nitrogen. All solvents were purchased from Kanto Chemical Co. Inc. (Tokyo, Japan), and were dried over activated molecular sieves. ${ }^{1} \mathrm{H},{ }^{11} \mathrm{~B}$, and ${ }^{11} \mathrm{~B}\left\{{ }^{1} \mathrm{H}\right\} \mathrm{NMR}$ spectra were recorded on a JEOL Lambda 400 spectrometer at ambient temperature unless otherwise noted. ${ }^{1} \mathrm{H}$ NMR chemical shifts ( $\delta$ values) were given in ppm relative to the solvent signal, whereas ${ }^{11} \mathrm{~B} N \mathrm{NR}$ chemical shifts were given relative to the standard resonances $\left(\mathrm{NaBH}_{4}\right)$. Elemental analyses were performed by the Thermo Scientific FLASH 2000 Organic Elemental Analyzer. The starting compounds, $\mathrm{Ge}\left(\mathrm{SiMe}_{3}\right)_{4}$ and potassium tris(trimethylsilyl)germanide, $\mathrm{KGe}\left(\mathrm{SiMe}_{3}\right)_{3}$ [21], were synthesized by a method reported in the literature. All reagents were purchased from FUJIFILM Wako Chemicals (Osaka, Japan), Tokyo Chemical Industries Co., Ltd. (Tokyo, Japan) or Sigma-Aldrich (St. Louis, USA), and were used without further purification.

\subsection{Preparation of Potassium Tris(trimethylsilyl)germanide}

Potassium salt of germyl anion, $\mathrm{KGe}\left(\mathrm{SiMe}_{3}\right)_{3}$, was prepared from a reaction of $\mathrm{Ge}\left(\mathrm{SiMe}_{3}\right)_{4}(3.142 \mathrm{~g}$, $8.6 \mathrm{mmol})$ with $\mathrm{KO}^{\mathrm{t}} \mathrm{Bu}(1.009 \mathrm{~g}, 9.0 \mathrm{mmol})$ in THF $(40 \mathrm{~mL})$ at room temperature. The solvent was removed in vacuo, and the remaining crude product was then dried at $40{ }^{\circ} \mathrm{C}$ overnight to afford $\mathrm{KGe}\left(\mathrm{SiMe}_{3}\right)_{3}$ as pale yellow powder in $58 \%$ yield $(1.64 \mathrm{~g})$. Formation of $\mathrm{KGe}\left(\mathrm{SiMe}_{3}\right)_{3}$ was confirmed by ${ }^{1} \mathrm{H}$ NMR spectra.

\subsection{Synthesis of (THF) ${ }_{2} \mathrm{Fe}\left[\mathrm{Ge}\left(\mathrm{SiMe}_{3}\right)_{3}\right]_{2}(\mathbf{1})$}

In a $50 \mathrm{~mL}$ schlenk tube, $\mathrm{FeBr}_{2}(86.3 \mathrm{mg}, 0.4 \mathrm{mmol})$ was suspended in THF $(10 \mathrm{~mL})$, and THF $(5 \mathrm{~mL})$ solution of $\mathrm{KGe}\left(\mathrm{SiMe}_{3}\right)_{3}(278 \mathrm{mg}, 0.84 \mathrm{mmol})$ was then slowly added to this solution at room temperature. The solution was stirred at room temperature for $1 \mathrm{~h}$. In the course of this reaction, the color of the solution turned to dark red purple, and the solution was then centrifuged to remove the insoluble materials. The mother liquid was evaporated in vacuo, and the obtained solid was dissolved in pentane $(20 \mathrm{~mL})$. The solution was again centrifuged to remove the insoluble materials. The supernatant was collected, and THF $(1 \mathrm{~mL})$ was added. The solvent was concentrated to ca. $3 \mathrm{~mL}$, and the remaining solution was cooled at $-30{ }^{\circ} \mathrm{C}$. Complex 1 was obtained as red-purple crystals in $74 \%$ yield $(0.232 \mathrm{~g}) .{ }^{1} \mathrm{H}$ NMR $\left(400 \mathrm{MHz}\right.$, r.t., $\left.\mathrm{C}_{6} \mathrm{D}_{6}\right): \delta=8.67$ (brs, $\left.54 \mathrm{H}, \mathrm{SiMe}_{3}\right), 24.04$ (brs, $\left.8 \mathrm{H}, \mathrm{THF}\right)$, 29.43 (brs, $8 \mathrm{H}, \mathrm{THF}$ ). Magnetic susceptibility (Evans): $\mu_{\text {eff }}=4.85$ (in $\mathrm{C}_{6} \mathrm{D}_{6}, 20.0^{\circ} \mathrm{C}$ ). Anal. Calcd. for $\mathrm{C}_{26} \mathrm{H}_{70} \mathrm{O}_{2} \mathrm{Ge}_{2} \mathrm{Si}_{6} \mathrm{Fe}_{1}$ : C, 39.81; $\mathrm{H}, 8.99$. Found: $\mathrm{C}, 40.16 ; \mathrm{H}, 8.93$. 


\subsection{General Procedure for the Reduction of Carbonyl Compounds Catalyzed by $\mathbf{1}$}

Catalyst 1 ( $2.0 \mathrm{mg}, 0.003 \mathrm{mmol}, 0.1 \mathrm{~mol} \%$ ) was placed in a $10 \mathrm{~mL}$ flask, and the substrate, $\mathrm{Ph}_{2} \mathrm{SiH}_{2}$ $(1.28 \mathrm{mg}, 6.6 \mathrm{mmol}), 4$-acetylbiphenyl or 4-phenyl-2-butanone $(3 \mathrm{mmol})$, and dioxane $(0.5 \mathrm{~mL})$ were then added, in this order. The resulting mixture was stirred at room temperature for $4 \mathrm{~h}$, and the complete consumption of the substrate and the yield of the product were then confirmed by ${ }^{1} \mathrm{H} N \mathrm{NR}$ spectrum with anisole as an internal standard.

\subsection{General Procedure for the Catalytic Silylation of $\mathrm{N}_{2}$ Catalyzed by 1}

The following procedure is analogous to those reported in previous papers [12]. A $10 \mathrm{~mL}$ flask was charged with $\mathrm{KC}_{8}(270 \mathrm{mg}, 2.0 \mathrm{mmol})$ and THF $(5 \mathrm{~mL})$, and Complex $1(0.004 \mathrm{mmol}, 0.2 \mathrm{~mol}$ $\%)$ and $\mathrm{Me}_{3} \mathrm{SiCl}(0.25 \mathrm{~mL}, 2.0 \mathrm{mmol})$ was then added to this suspension. The remaining suspension was vigorously stirred at room temperature for $24 \mathrm{~h}$ under successive supply of $\mathrm{N}_{2}$ (1 atm). After the reaction, cyclododecane $(60 \mathrm{mg}, 0.36 \mathrm{mmol})$ was added as an internal standard, and the yield of the formed $\mathrm{N}\left(\mathrm{SiMe}_{3}\right)_{3}$ was then determined by GC/GC-MS.

\subsection{General Procedure for the Dehydrogeantion of Ammonia Borane Catalyzed by $\mathbf{1}$}

Catalyst 1 ( $20 \mathrm{mg}, 0.025 \mathrm{mmol}, 5 \mathrm{~mol} \%)$ was dissolved in THF ( $2 \mathrm{~mL})$ in a $4 \mathrm{~mL}$ reaction vessel, and the additives shown in Tables S1 or S2 in the supporting information were then added to this solution. The obtained solution was stirred for $15 \mathrm{~min}$ at room temperature, and ligands shown in Tables S1 or S2 were then added. After stirring this solution for $15 \mathrm{~min}$ at room temperature, the obtained solution was added to THF $(2 \mathrm{~mL})$ solution of ammonia borane (15 $\mathrm{mg}, 0.5 \mathrm{mmol})$. The resulting mixture was stirred at $55{ }^{\circ} \mathrm{C}$ for the time indicated in Tables S1 and S2. Conversion of ammonia borane was confirmed by ${ }^{11} \mathrm{~B}$ and ${ }^{11} \mathrm{~B}\left\{{ }^{1} \mathrm{H}\right\}$ NMR spectrum.

\subsection{Synthesis of Dinuclear Iron Complex, $\left[\mathrm{Ge}\left(\mathrm{SiMe}_{3}\right)_{3}\right] \mathrm{Fe}\left(\mu-\mathrm{O}^{t} \mathrm{Bu}\right)_{2} \mathrm{Fe}(\mathrm{THF})\left[\mathrm{Ge}\left(\mathrm{SiMe}_{3}\right)_{3}\right](\mathbf{6})$}

In a $50 \mathrm{~mL}$ schlenk tube, Complex $1(335 \mathrm{mg}, 0.43 \mathrm{mmol})$ was dissolved in THF $(2 \mathrm{~mL})$, and ${ }^{\mathrm{t}} \mathrm{BuOH}$ $(40 \mu \mathrm{L}, 0.43 \mathrm{mmol}$ ) was added to this solution at room temperature. The solution was stirred at room temperature for $1 \mathrm{~h}$. In the course of this reaction, the color of the solution turned from dark red purple to brown, and the solvent was then removed in vacuo. The crude product was dissolved in pentane $(1 \mathrm{~mL})$, and the remaining solution was cooled at $-20^{\circ} \mathrm{C}$. Complex 6 was obtained as brown crystals in $\sim 5 \%$ yield. The molecular structure of 6 was exclusively determined by $\mathrm{X}$-ray diffraction analysis.

Complex 6 was alternatively obtained from the reaction of $\mathrm{FeBr}_{2}, \mathrm{KGe}\left(\mathrm{SiMe}_{3}\right)_{3}$, and $\mathrm{KO}^{\mathrm{t}} \mathrm{Bu}$. Iron dibromide $(216 \mathrm{mg}, 1.0 \mathrm{mmol})$ was dissolved in THF $(2 \mathrm{~mL})$, and a $\mathrm{KO}^{\mathrm{t}} \mathrm{Bu}(112 \mathrm{mg}, 1.0 \mathrm{mmol})$ and THF $(3 \mathrm{~mL})$ solution of $\mathrm{KGe}\left(\mathrm{SiMe}_{3}\right)_{3}$, prepared in situ from the reaction of $\mathrm{Ge}\left(\mathrm{SiMe}_{3}\right)_{4}(385$ $\mathrm{mg}, 1.05 \mathrm{mmol})$ and $\mathrm{KO}^{\mathrm{t}} \mathrm{Bu}(123 \mathrm{mg}, 1.1 \mathrm{mmol})$, was added to this solution at room temperature. The solution was stirred at room temperature for $1 \mathrm{~h}$. The solution was centrifuged to remove insoluble materials, and the mother liquid was dried under vacuum. The remaining crude product was dissolved in pentane $(5 \mathrm{~mL})$, and centrifuged to remove a small amount of insoluble materials, and the mother liquid was then concentrated to ca. $1 \mathrm{~mL}$. After cooling this solution at $-20^{\circ} \mathrm{C}$, Complex 6 was obtained as brown crystals. The cell parameters of the obtained crystals were consistent with those found in crystals of $\mathbf{6}$, which was synthesized in the procedure described above.

\subsection{X-ray Data Collection and Reduction}

X-ray crystallography for Complexes $\mathbf{1}$ and $\mathbf{6}$ was performed on a Rigaku Saturn CCD area detector with graphite monochromated Mo-K $\alpha$ radiation $(\lambda=0.71075 \AA)$. The data were collected at 183(2) K using a $\omega$ scan in the $\theta$ range of $3.01 \leq \theta \leq 27.45 \mathrm{deg}$ for $\mathbf{1}$ and $3.28 \leq \theta \leq 27.48 \mathrm{deg}$ for $\boldsymbol{6}$. The data obtained were processed using Crystal-Clear (Rigaku) on a Pentium computer, and were corrected for Lorentz and polarization effects. The structures were solved by direct methods [45], and expanded using Fourier techniques. Hydrogen atoms were refined using the riding model. 
The final cycle of full-matrix least-squares refinement on $F^{2}$ was based on 5750 observed reflections and 188 variable parameters for 1 and 11,471 observed reflections and 388 variable parameters for $\mathbf{6}$. Neutral atom scattering factors were taken from International Tables for Crystallography (IT), Vol. C, Table 6.1.1.4 [46]. Anomalous dispersion effects were included in Fcalc [47]; the values for $\Delta f^{\prime}$ and $\Delta \mathrm{f}^{\prime \prime}$ were those of Creagh and McAuley [48]. The values for the mass attenuation coefficients are those of Creagh and Hubbell [49]. All calculations were performed using the CrystalStructure [50] crystallographic software package except for refinement, which was performed using SHELXL Version 2017/1 [51]. Details of the final refinement as well as the bond lengths and angle are summarized in Tables S3 and S4, and the numbering scheme employed is shown in Figures S3 and S4, which were drawn with ORTEP at 50\% probability ellipsoids. CCDC numbers 1971242 (1) and 1971243 (6) contain the supplementary crystallographic data for this paper. These data can be obtained free of charge from the Cambridge Crystallographic Data Centre via www.ccdc.cam.ac.uk/data_request/cif.

\section{Conclusions}

In summary, we have described a facile synthesis of the four-coordinated iron-digermyl complex 1 via the reaction of $\mathrm{FeBr}_{2}$ and in-situ-generated $\mathrm{KGe}\left(\mathrm{SiMe}_{3}\right)_{3}$. Complex 1 shows high catalytic performance in the hydrosilylation of ketones and in the reductive silylation of dinitrogen. Additionally, 1 acts as a good precursor for the catalytic dehydrogenation of ammonia borane $\left(\mathrm{NH}_{3} \cdot \mathrm{BH}_{3}\right)$ in the presence of ${ }^{\mathrm{t}} \mathrm{BuNH}_{2}$ and phenanthroline. It should be emphasized that the catalytic dehydrogenation of $\mathrm{NH}_{3} \cdot \mathrm{BH}_{3}$ was realized using a catalyst system consisting of stable and easy-to-handle precursors. The use of the organogermyl ligand was found to contribute to both the generation of coordinatively unsaturated reactive complexes and the isolation of a key intermediary species involved in the catalysis. Efforts to develop efficient base-metal catalysts based on the introduction of heavier-group-14 ligands are currently in progress in our laboratory.

Supplementary Materials: The following are available online at http://www.mdpi.com/2073-4344/10/1/29/s1: CIF and cif-checked files, detailed crystallographic data, detailed results obtained by the dehydrogenation of ammonia borane catalyzed by $\mathbf{1}$ in the presence of various ligands and additives, the actual NMR charts of Complex $\mathbf{1}$, and the crude product obtained from the hydrogenation ammonia borane catalyzed by 1 .

Author Contributions: Y.S. conceived and designed the experiments; Y.K performed the experiments; Y.K. and Y.S. analyzed the data; Y.S. wrote the paper. All authors have read and agreed to the published version of the manuscript.

Funding: This research was funded by a Grant in Aid for Scientific Research (B) (No. 16H04120) and a Grant in Aid for Scientific Research on Innovative Areas "Precise Formation of a Catalyst Having a Specified Field for Use in Extremely Difficult Substrate Conversion Reactions" (No. 18H04240) from the Ministry of Education, Culture, Sports, Science and Technology, Japan. This work was also supported by Iketani Science and Technology Foundation, and the special fund of the Institute of Industrial Science, The University of Tokyo.

Conflicts of Interest: The authors declare that there is no conflict of interest. 


\section{References}

1. Corey, J.Y. Reactions of Hydrosilanes with Transition Metal Complexes. Chem. Rev. 2016, 116, 11291-11435. [CrossRef] [PubMed]

2. Corey, J.Y. Reactions of Hydrosilanes with Transition Metal Complexes and Characterization of the Products. Chem. Rev. 2011, 111, 863-1071. [CrossRef] [PubMed]

3. Corey, J.Y.; Braddock-Wilking, J. Reactions of Hydrosilanes with Transition-Metal Complexes: Formation of Stable Transition-Metal Silyl Compound. Chem. Rev. 1999, 99, 175-292. [CrossRef] [PubMed]

4. Tanabe, M.; Osakada, K. Sila-and Germametallacycles of Late Transition Metals. Organometallics 2010, 29, 4702-4710. [CrossRef]

5. Tilley, T.D. Transition-Metal Silyl Derivatives. In The Chemistry of Organic Silicon Compounds; Patai, S., Rappoport, Z.J., Eds.; Wiley and Sons: New York, NY, USA, 1989; pp. 1415-1477.

6. Marek, I.; Rappoport, Z. The Chemistry of Organoiron Compounds; Patai, S., Rappoport, Z.J., Eds.; Wiley and Sons: New York, NY, USA, 2014.

7. Plietker, B. (Ed.) Iron Catalysis in Organic Chemistry; WILEY-VCH: Weinheim, Germany, 2008.

8. Nakamura, E.; Yoshikai, N. Low-Valent Iron-Catalyzed C-C Bond Formation-Addition, Substitution, and C-H Bond Activation. J. Org. Chem. 2010, 75, 6061-6067. [CrossRef]

9. Bauer, I.; Knölker, H.-J. Iron Catalysis in Organic Synthesis. Chem. Rev. 2015, 115, 3170-3387. [CrossRef]

10. Sun, C.-L.; Li, B.-J.; Shi, Z.-J.; Direct, C.-H. Transformation via Iron Catalysis. Chem. Rev. 2011, 111, $1293-1314$. [CrossRef]

11. Bolm, C.; Legros, J.; LePaih, J.; Zani, L. Iron-Catalyzed Reactions in Organic Synthesis. Chem. Rev. 2004, 104, 6217-6254. [CrossRef]

12. Arata, S.; Sunada, Y. An isolable iron(ii) bis(supersilyl) complex as an effective catalyst for reduction reactions. Dalton Trans. 2019, 48, 2891-2895. [CrossRef]

13. Zhu, C.; Takaya, J.; Iwasawa, N. Use of Formate Salts as a Hydride and a $\mathrm{CO}_{2}$ Source in PGeP-Palladium Complex-CatalyzedHydrocarboxylation of Allenes. Org. Lett. 2015, 17, 1814-1817. [CrossRef]

14. Takaya, J.; Nakamura, S.; Iwasawa, N. Synthesis, Structure, and Catalytic Activity of Palladium Complexes Bearing a Tridentate PXP-Pincer Ligand of Heavier Group 14 Element (X=Ge, Sn). Chem. Lett. 2012, 41, 967-969. [CrossRef]

15. Takaya, J.; Iwasawa, N. Synthesis, Structure, and Reactivity of a Mononuclear $\eta^{2}-(\mathrm{Ge}-\mathrm{H})$ palladium(0) Complex Bearing a PGeP-Pincer-Type Germyl Ligand: Reactivity Differences between Silicon and Germanium. Eur. J. Inorg. Chem. 2018, 2018, 5012-5018. [CrossRef]

16. Barrau, J.; Hamida, N.B.; Agrebi, A.; Satge, J. Bis(dimethylgermyl)alkane-iron tetracarbonyls: Synthesis, photolysis, and reactivity. Organometallics 1989, 8, 1585-1593. [CrossRef]

17. Itazaki, M.; Kamitani, M.; Hashimoto, Y.; Nakazawa, H. Synthesis, Characterization, and Crystal Structure of Germyl(phosphine)iron Complexes, $\mathrm{Cp}(\mathrm{CO}) \mathrm{Fe}\left(\mathrm{PPh}_{3}\right)\left(\mathrm{GeR}_{3}\right)\left(\mathrm{R}=\mathrm{Et},{ }^{n} \mathrm{Bu}, \mathrm{Ph}\right)$, Prepared from $\mathrm{Cp}(\mathrm{CO}) \mathrm{Fe}\left(\mathrm{PPh}_{3}\right)(\mathrm{Me})$ and $\mathrm{HGeR}_{3}$. Phosphorus Sulfur Silicon Relat. Elem. 2010, 185, 1054-1060. [CrossRef]

18. Itazaki, M.; Kamitani, M.; Nakazawa,H. Trans-selective hydrogermylation of alkynes promoted by methyliron and bis(germyl)hydridoiron complexes as a catalyst precursor. Chem. Commun. 2011, 47, 7854-7856. [CrossRef] [PubMed]

19. Itazaki, M.; Kamitani, M.; Ueda, K.; Nakazawa, H. Syntheses and Ligand Exchange Reaction of Iron(IV) Complexes with Two Different Group 14 Element Ligands, $\mathrm{Cp}(\mathrm{CO}) \mathrm{FeH}\left(\mathrm{EEt}_{3}\right)\left(\mathrm{E}^{\prime} \mathrm{Et}_{3}\right)\left(\mathrm{E}, \mathrm{E}^{\prime}=\mathrm{Si}, \mathrm{Ge}, \mathrm{Sn}\right)$. Organometallics 2009, 28, 3601-3603. [CrossRef]

20. Anema, S.G.; Mackay, K.M.; Nicholson, B.K.; Tiel, M.V. Synthesis of iron carbonyl clusters with trigonal-bipyramidal $\mathrm{E}_{2} \mathrm{Fe}_{3}$ cores $(\mathrm{E}=\mathrm{Ge}, \mathrm{Si})$. Crystal structures of $\left(\mu_{3}-\mathrm{GeEt}\right)_{2} \mathrm{Fe}_{3}(\mathrm{CO})_{9}$, $\left[\mu_{3}-\mathrm{Ge}\left\{\mathrm{Fe}(\mathrm{CO})_{2} \mathrm{Cp}\right\}\right]_{2} \mathrm{Fe}_{3}(\mathrm{CO})_{9}$, and $\left[\mu_{3}-\mathrm{Si}\left\{\mathrm{Fe}(\mathrm{CO})_{2} \mathrm{Cp}\right\}\right]_{2} \mathrm{Fe}_{3}(\mathrm{CO})_{9}$. Organometallics 1990, 9, $2436-2442$. [CrossRef]

21. Fischer, J.; Baumgartner, J.; Marschner, C. Silylgermylpotassium Compounds. Organometallics 2005, 24, 1263-1268. [CrossRef]

22. Okazaki, M.; Kimura, H.; Komuro, T.; Okada, H.; Tobita, H. Synthesis, Structure, and Properties of Three-and Six-Membered Metallacycles Composed of Iron, Germanium, and Sulfur Atoms. Chem. Lett. 2007, 36, 990-991. [CrossRef] 
23. Tobita, H.; Ishiyama, K.; Kawano, Y.; Inomata, S.; Ogino, H. Synthesis of Cationic Germyleneiron Complexes and X-ray Structure of $\left[\mathrm{Cp}^{*}(\mathrm{CO})_{2} \mathrm{FeGeMe}_{2} \cdot \mathrm{DMAP}_{\mathrm{BPh}} \cdot \mathrm{CH}_{3} \mathrm{CN}\left(\mathrm{Cp}^{*}=\mathrm{C}_{5} \mathrm{Me}_{5}, \mathrm{DMAP}=\right.\right.$ 4-(Dimethylamino)pyridine). Organometallics 1998, 17, 789-794. [CrossRef]

24. Meier-Brocks, F.; Weiss, E. Tetraphenylzirkonacyclopentadien-derivate als synthone für tetraphenylthiophenmonoxid und substituierte germanole. J. Organomet. Chem. 1993, 453, $33-45$. [CrossRef]

25. Xie, W.; Wang, B.; Dai, X.; Xu, S.; Zhou, X. Novel Rearrangement Reactions. 3. Thermal Rearrangement of the Diruthenium Complex $\left(\mathrm{Me}_{2} \mathrm{SiSiMe}_{2}\right)\left[\left(\eta^{5}-\mathrm{C}_{5} \mathrm{H}_{4}\right) \mathrm{Ru}(\mathrm{CO})\right]_{2}(\mu-\mathrm{CO})_{2}$. Organometallics 1998, 17, 5406-5410. [CrossRef]

26. Wang, B.; Zhu, B.; Zhang, J.; Xu, S.; Zhou, X.; Weng, L. Reactions of Doubly Bridged Bis(cyclopentadienes) with Iron Pentacarbonyl. Organometallics 2003, 22, 5543-5555. [CrossRef]

27. Schubert, E.M. Utilizing the Evans method with a superconducting NMR spectrometer in the undergraduate laboratory. J. Chem. Educ. 1992, 69, 62. [CrossRef]

28. Piguet, C. Paramagnetic Susceptibility by NMR: The "Solvent Correction" Removed for Large Paramagnetic Molecules. J. Chem. Educ. 1997, 74, 815-816. [CrossRef]

29. Bain, G.A.; Berry, J.F. Diamagnetic Corrections and Pascal's Constants. J. Chem. Educ. 2008, 85, 532-536. [CrossRef]

30. Rossin, A.; Peruzzini, M. Ammonia-Borane and Amine-Borane Dehydrogenation Mediated by Complex Metal Hydrides. Chem. Rev. 2016, 116, 8848-8872. [CrossRef]

31. Balaraman, E.; Nandakumar, A.; Jaiswal, G.; Sahoo, M.K. Iron-catalyzed dehydrogenation reactions and their applications in sustainable energy and catalysis. Catal. Sci. Technol. 2017, 7, 3177-3195. [CrossRef]

32. Coles, N.T.; Webster, R.L. Iron Catalyzed Dehydrocoupling of Amine-and Phosphine-Boranes. Isr. J. Chem. 2017, 57, 1070-1081. [CrossRef]

33. Baker, R.T.; Gordon, J.C.; Hamilton, C.W.; Henson, N.J.; Lin, P.-H.; Maguire, S.; Murugesu, M.; Scott, B.L.; Smythe, N.C. Iron Complex-Catalyzed Ammonia-Borane Dehydrogenation. A Potential Route toward B-N-Containing Polymer Motifs Using Earth-Abundant Metal Catalysts. J. Am. Chem. Soc. 2012, 134, 5598-5609. [CrossRef]

34. Glüer, A.; Förster, M.; Celinski, V.R.; Schmedt auf der Günne, J.; Holthausen, M.C.; Schneider, S. Highly Active Iron Catalyst for Ammonia Borane Dehydrocoupling at Room Temperature. ACS Catal. 2015, 5, 7214-7217. [CrossRef]

35. Vance, J.R.; Robertson, A.P.M.; Lee, K.; Manners, I. Photoactivated, Iron-Catalyzed Dehydrocoupling of Amine-Borane Adducts: Formation of Boron-Nitrogen Oligomers and Polymers. Chem. Eur. J. 2011, 17, 4099-4103. [CrossRef] [PubMed]

36. Vance, J.R.; Schäfer, A.; Robertson, A.P.M.; Lee, K.; Turner, J.; Whittell, G.R.; Manners, I. Iron-Catalyzed Dehydrocoupling/Dehydrogenation of Amine-Boranes. J. Am. Chem. Soc. 2014, 136, 3048-3064. [CrossRef] [PubMed]

37. Pagano, J.K.; Bange, C.A.; Farmiloe, S.E.; Waterman, R. Visible Light Photocatalysis Using a Commercially Available Iron Compound. Organometallics 2017, 26, 3891-3895. [CrossRef]

38. Bhattacharya, P.; Krause, J.A.; Guan, H. Mechanistic Studies of Ammonia Borane Dehydrogenation Catalyzed by Iron Pincer Complexes. J. Am. Chem. Soc. 2014, 136, 11153-11161. [CrossRef]

39. Kuroki, A.; Ushiyama, H.; Yamashita, K. Theoretical studies on ammonia borane dehydrogenation catalyzed by iron pincer complexes. Comput. Theor. Chem. 2016, 1090, 214-217. [CrossRef]

40. Gorgas, N.; Stöger, B.; Veiros, L.F.; Kirchner, K. Access to FeII Bis $(\sigma-B-H)$ Aminoborane Complexes through Protonation of a Borohydride Complex and Dehydrogenation of Amine-Boranes. Angew. Chem. Int. Ed. 2019, 58, 13874-13879. [CrossRef]

41. Coles, N.T.; Mahon, M.F.; Webster, R.L. Phosphine-and Amine-Borane Dehydrocoupling Using a Three-Coordinate Iron(II) $\beta$-Diketiminate Precatalyst. Organometallics 2017, 36, 2262-2268. [CrossRef]

42. Bäcker, A.; Li, Y.; Fritz, M.; Grätz, M.; Ke, Z.; Langer, R. Redox-Active, Boron-Based Ligands in Iron Complexes with Inverted Hydride Reactivity in Dehydrogenation Catalysis. ACS Catal. 2019, 9, 7300-7309. [CrossRef]

43. Alig, L.; Fritz, M.; Schneider, S. First-Row Transition Metal (De)Hydrogenation Catalysis Based On Functional Pincer Ligands. Chem. Rev. 2019, 119, 2681-2751. [CrossRef] 
44. Todisco, S.; Luconi, L.; Giambastiani, G.; Rossin, A.; Peruzzini, M.; Golub, I.E.; Filippov, O.A.; Belkova, N.V.; Shubina, E.S. Ammonia Borane Dehydrogenation Catalyzed by $\left(\kappa^{4}-\mathrm{EP}_{3}\right) \mathrm{Co}(\mathrm{H})\left[\mathrm{EP}_{3}=\mathrm{E}\left(\mathrm{CH}_{2} \mathrm{CH}_{2} \mathrm{PPh}_{2}\right)_{3} ; \mathrm{E}=\right.$ $\mathrm{N}, \mathrm{P}$ ] and $\mathrm{H}_{2}$ Evolution from Their Interaction with $\mathrm{NH}$ Acids. Inorg. Chem. 2017, 56, 4296-4307. [CrossRef] [PubMed]

45. Burla, M.C.; Caliandro, R.; Camalli, M.; Carrozzini, B.; Cascarano, G.L.; De Caro, L.; Giacovazzo, C.; Polidori, G.; Siliqi, D.; Spagna, R. IL MILIONE: a suite of computer programs for crystal structure solution of proteins. J. Appl. Cryst. 2007, 40, 609-613. [CrossRef]

46. Creagh, D.C.; McAuley, W.J. International Tables for Crystallography; Table 6.1.1.4; Wilson, A.J.C., Ed.; Kluwer Academic Publishers: Dordrecht, The Netherlands, 1992; p. 572.

47. Ibers, J.A.; Hamilton, W.C. Dispersion corrections and crystal structure refinements. Acta Cryst. 1964, 17, 781-782. [CrossRef]

48. Creagh, D.C.; McAuley, W.J. International Tables for Crystallography; Table 4.2.6.8; Wilson, A.J.C., Ed.; Kluwer Academic Publishers: Dordrecht, The Netherlands, 1992; pp. 219-222.

49. Creagh, D.C.; Hubbell, J.H. International Tables for Crystallography; Table 4.2.4.3; Wilson, A.J.C., Ed.; Kluwer Academic Publishers: Dordrecht, The Netherlands, 1992; pp. 200-206.

50. CrystalStructure 4.2.5: Crystal Structure Analysis Package; Rigaku Corporation: Tokyo 196-8666, Japan, 2000-2017.

51. Sheldrick, G.M. SHELXL Version 2017/1: A short history of SHELX. Acta Cryst. 2008, 64, 112-122. [CrossRef] [PubMed]

(C) 2019 by the authors. Licensee MDPI, Basel, Switzerland. This article is an open access article distributed under the terms and conditions of the Creative Commons Attribution (CC BY) license (http://creativecommons.org/licenses/by/4.0/). 